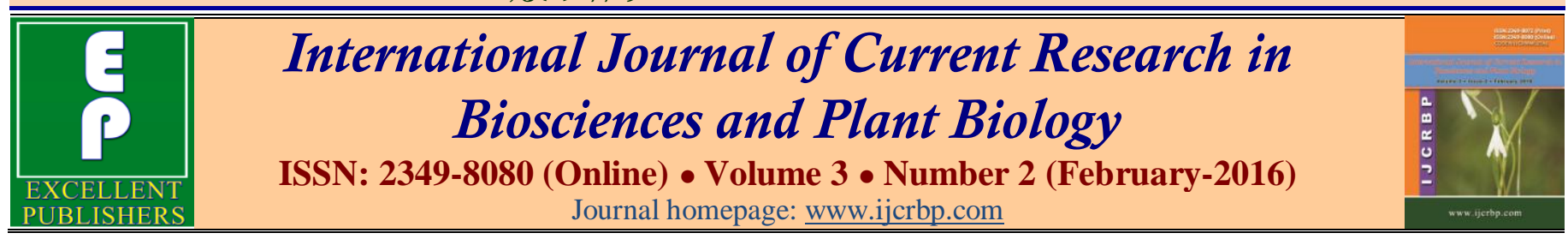

\title{
Bark Traits of Woody Species and Bark Resource Use by Faunal Community in Tropical Dry Evergreen Forest of India
}

\author{
K. Anil and N. Parthasarathy* \\ Department of Ecology and Environmental Sciences, Pondicherry University, Puducherry 605 014, India \\ *Corresponding author.
}

\section{Abstract}

Bark can help to defend trees and lianas against abiotic and biotic disturbances. Bark traits have long been used to characterise tree fire resistance and physical features like texture, anatomy, fissure and sealing can influence the effectiveness of bark in protecting trees from fire, herbivory and microbial infections. We investigated bark traits of 105 woody species (60 trees and 45 lianas) in Indian tropical dry evergreen forest, and the relationship between bark thickness and sap quantity with faunal diversity, to assess the ecological use of bark resources as space and food by various fauna in tropical dry evergreen forest. Bark thickness of tree species in the studied forest varied from 0.02 to $2.23 \pm 0.22 \mathrm{~cm}$ (maximum for Garcinia spicata and least for Gmelina asiatica) and those of lianas varied from 0.01 to $1.23 \pm 0.02 \mathrm{~cm}$ (maximum for Plecospermum spinosum and least for Cissus quadrangularis). A total of thirteen species of tree nesters and five species of wood borers utilized bark resource in tropical dry evergreen forest and most common among them include termites $(30.47 \%)$ followed by ants and millipedes. The association between bark traits and faunal occurrence was analysed with principal component analysis (PCA) and trade-offs were ascertained with bivariate Pearson correlation. Evidently bark texture, fissure and thickness play a positive role in accommodating fauna $(p<0.01)$ in tropical dry evergreen forest. The co-occurrence among bark faunal groups is also evident and the highest values of co-occurrence were recorded for ants - millipedes. Our results reveal that bark traits of woody species provide suitable habitat for wood borers and tree nesters. This study provides a ground work for further investigation on the functional aspects of bark in tropical woody species.
\end{abstract}

\section{Introduction}

Bark of woody species, as compared with other plant parts has been little studied besides its use in providing criteria for plant identification. The term bark designates all tissues external to the vascular cambium, comprising secondary phloem, periderm and nonconductive tissues external to the periderm (Evert et al., 2006). Whitmore (1962) introduced certain criteria for the identification and classification of different species on the basis of bark morphology. Bark can help to defend trees and lianas

\section{Article Info}

Accepted: 28 January 2016

Available Online: 06 February 2016

\section{Ke ywords}

Bark fissure

Bark thickness

Faunal diversity

Sap quantity

Stem girth

Tropical dry evergreen forest against various abiotic and biotic disturbances. Regardless of the nature of the disturbance, if bark plays an important role in defence, its thickness should increase asymptotically as an individual grows to certain extent and beyond this growth additional thickness confers no further survival advantage (Wilson and Witkowski, 2003). Bark traits have long been used to characterise tree fire resistance (Gorman, 1989; Agee, 1993). Physical features like texture, anatomy, fissure and sealing can influence the effectiveness of bark in protecting woody species from fire (Harmon, 1984; Vines, 1968), herbivory and microbial 
infections (Romberger et al., 1992). Jacobs (1988) observed that tropical forest trees with a thick bark or a bark rich in moisture such as Eucalyptus spp. have a better chance of withstanding fires. Apart from fire insulation, bark accomplishes many other functions including provision of structural support, reduction in water loss by stems, defence against herbivores, pathogens and injury by large mammals (Paine et al., 2010; Romero, 2013; Poorter et al., 2014).

Levin (1976) showed that bark of woody species in disturbed forests in Gabon was more frequently associated with toxic chemicals than the woody species characteristic of less disturbed forest. The threat posed to trees by pathogens and sap-feeding herbivores may also affect bark thickness. In the Neotropics, marmosets (Callithrix spp.) feed on exudates from holes they gouge in trees (CoimbraFilho and Mittermeier, 1976). In North America, sapsuckers (Sphyrapicus spp.) extract sap from the extensive series of holes they bore through bark, preferentially selecting species that produce more sap (Eberhardt, 2000). Bark texture can influence the density, diversity and locomotion of both sessile and mobile organisms on tree bark in temperate forest (Cramer, 1975; Stephenson, 1989) and smooth texture bark on tree was hypothesized to be anatomical defences against insect attack (Ferrenberg and Mitton, 2014).

Wood-feeding insects attack live trees, which can create widespread disturbances in forests (Schowalter, 2000). In temperate forests, primary consumption by wood-boring insects can cause structural and functional disruption of primary and secondary growth of trees (Feller, 2002; Barbosa and Wagner, 1989) and can affect tree architecture, growth, reproduction and sex expression (Whitham and Mopper, 1985). Wood borers also play an important role in nutrient cycling, gap formation and succession in temperate ecosystem (Amman, 1976; Schowalter, 1981; Landquist, 2000). Wood borers can prune, weaken, or kill standing trees, thereby reducing the timber quality of both temperate and tropical species (Grijpma, 1970; Grijpma and Gara, 1970; Howard, 1991; Yamazaki et al., 1992). Barks hollowed by wood borers are used as nest site by ants and spiders, as food sources by numerous dead wood feeders and as a host site for parasites (Feller and Mathis, 1997).

At the community-level, few studies are available regarding the bark characteristics (Pinard and Huffman, 1997; Hegde et al., 1998; Paine et al., 2010; Poorter et al., 2014). Tropical dry evergreen forests (TDEF) are found along the east coast of India and mostly occur as small, isolated fragments of varying sizes $(0.5$ to $\approx 10 \mathrm{ha})$ in peninsular India. Plant diversity is well documented in these forests (Parthasarathy et al., 2008), but intensive ecological studies critical for conservation and for planning restoration activities are warranted. There have been no studies on bark traits and faunal occurrence at the community level in TDEF and hence this research was undertaken in the less-studied tropical dry evergreen forest on the Coromandel Coast of peninsular India. We studied bark traits and faunal utilization of 105 woody species: sixty trees and forty- five lianas in fragments of TDEF in southern India, as to assess the ecological use of bark as a resource for space and food by various fauna. We addressed two questions: first, how are bark traits and bark faunal groups related? Second, what is the importance of bark as a resource in forest ecosystem? We hypothesised that (i) there is a positive relationship between bark traits and bark faunal groups and (ii) bark and bark faunal groups play significant role in forest ecosystem.

\section{Materials and methods}

\section{Study area}

The terrestrial vegetation distributed along the east coast of India is described as tropical dry evergreen forest which inland up to $50 \mathrm{~km}$ (Champion and Seth 1968; Mani and Parthasarathy 2006; Parthasarathy et al., 2008). These closed-canopy forests have two distinct layers of tree species. The canopy is about 10-12 meter in height, dominated by large trees such as Pterospermum canescens and Garcinia spicata, while the sub-canopy is composed of smaller trees such as Memecylon umbellatum and Canthium dicoccum. For the present study, we selected a total of nine tropical dry evergreen forest sites, as to cover all woody plant species of TDEF. These sites are located in Villupuram $\left(11^{\circ} 56^{\prime} \mathrm{N}\right.$ and $79^{\circ} 53^{\prime} \mathrm{E}$ ) and Cuddalore $\left(11^{\circ} 43^{\prime} \mathrm{N}\right.$ and $\left.79^{\circ} 49^{\prime} \mathrm{E}\right)$ ) districts of Tamil Nadu on the Coromandel Coast of peninsular India. Site Puthupet (PP$12^{\circ} 03^{\prime} \mathrm{N}$ and $79^{\circ} 52^{\prime} \mathrm{E}$ ), Oorani (OR- $12^{\circ} 09^{\prime} \mathrm{N}$ and $79^{\circ} 52^{\prime}$ E) and Vada Agaram (VA- $72^{\circ} 10^{\prime} \mathrm{N}$ and $79^{\circ} 55^{\prime} \mathrm{E}$ ) are located respectively 15,28 and $32 \mathrm{~km}$ north of Puducherry $\left(11^{\circ} 56^{\prime} \mathrm{N}\right.$ and $\left.79^{\circ} 53^{\prime} \mathrm{E}\right)$ and seven other sites Kuzhandhaikuppam (KK- $11^{\circ} 43^{\prime} \mathrm{N}$ and $79^{\circ} 38^{\prime} \mathrm{E}$ ), Thirumanikkuzhi (TM- $11^{\circ} 43^{\prime} \mathrm{N}$ and $79^{\circ} 41 \mathrm{E}$ ), Suriyanpet (SR- $11^{\circ} 44^{\prime} \mathrm{N}$ and $79^{\circ} 38^{\prime} \mathrm{E}$ ), Sendhirakillai (SK- $11^{\circ} 30^{\prime} \mathrm{N}$ and $79^{\circ} 41 \mathrm{E}$ ), Palvathunnan (PT-11 $1^{\circ} 32^{\prime} \mathrm{N}$ and $79^{\circ} 41^{\prime} \mathrm{E}$ ) and Kothattai (KT- $11^{\circ} 30^{\prime} \mathrm{N}$ and $79^{\circ} 42^{\prime} \mathrm{E}$ ) are located around 45 to $50 \mathrm{~km}$ south of Puducherry. The forest area of each study site ranges from 1.2 to 10 ha. Fifty-year (1954 to 2014) climate data of the ten sites revealed a mean annual temperature of $28.3^{\circ} \mathrm{C}$ and the mean annual rainfall 
of $1,171 \mathrm{~mm}$ (www. world clim.com). The mean number of rainy days in the annual cycle is 55.5. The climate is tropical dissymmetric type with the bulk of the rainfall received during the northeast monsoon (OctoberDecember). Soils are red ferralitic belonging to the Cuddalore sandstone formation of the Miocene period (Meher-Homji, 1974). Major tree species of this forest type include Memecylon umbellatum Burm. f., Garcinia spicata (Wight \& Arn.) J.D. Hook., Tricalysia sphaerocarpa
(Dalz.) Gamble, Lepisanthes tetraphylla (Vahl) Radlk., Atalantia monophylla (L.) Correa and Pterospermum canescens Roxb., and major lianas include Strychnos lenticellata Dennst., Combretum albidum G. Don., Reissantia indica (Willd.) Halle, Pyrenacantha volubilis Wight and Capparis zeylanica L.; Ecbolium viride (Forsskal) Alston and Sansevieria roxburghiana Schultes $\&$ Schultes f. are the major native perennial herbs present in this forest type (Parthasarathy et al., 2008).
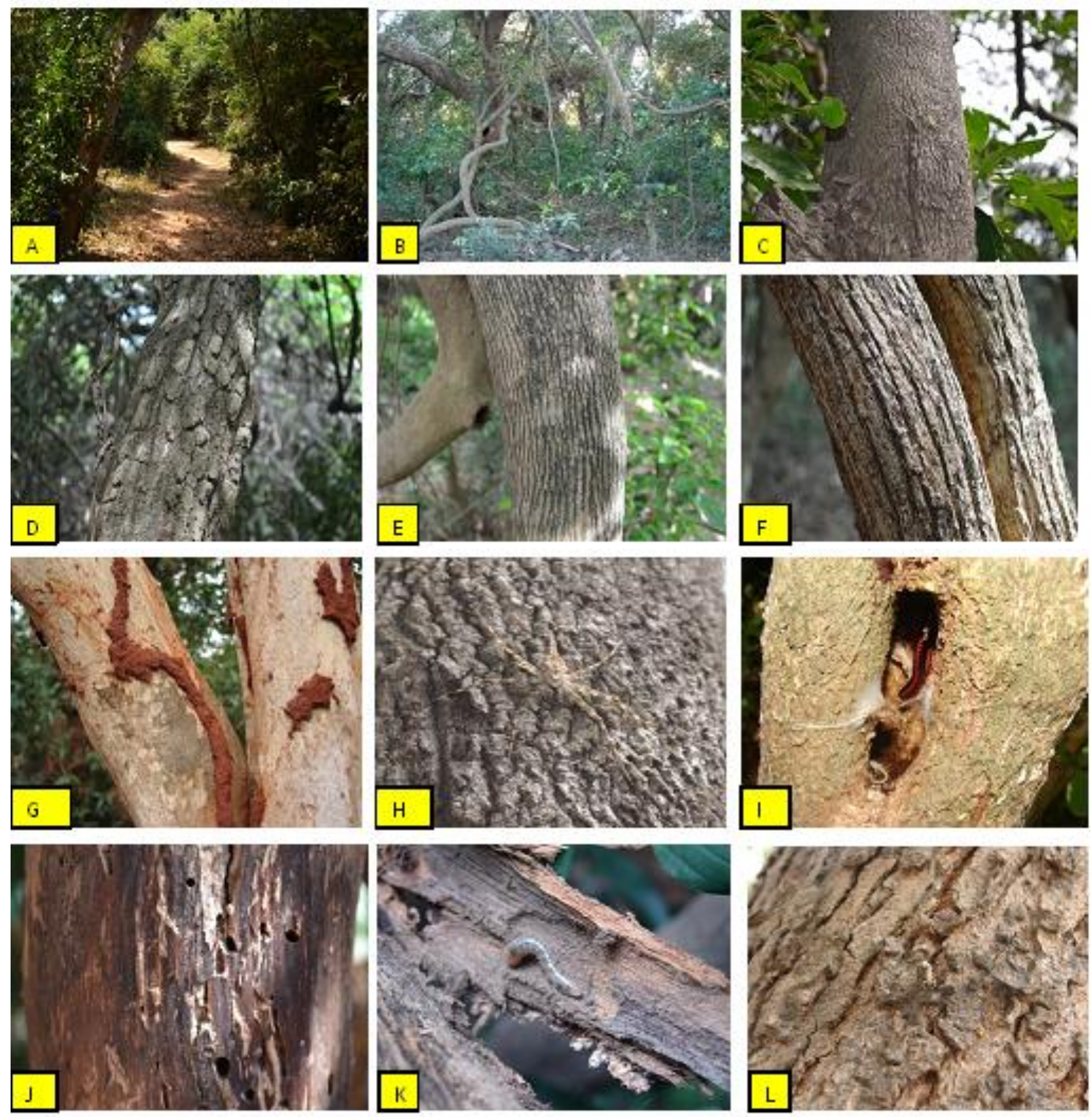

Fig. 1: Photograph depicting view of study site, forest stand view, bark of woody species exhibiting a range of bark traits and bark resource users in the tropical dry evergreen forest on the Coromandel Coast of India. (A) Purangani forest view. (B) Oorani forest interior. (C) Rough bark of Diospyros ebenum. (D) Rough bark of Morinda coreia. (E) Slightly rough bark of Memecylon umbellatum. (F) Slightly rough bark of the liana Reissantia indica. (G) Cryptotermes sp. on smooth-barked tree, Tricalysia sphaerocarpa. (H) Hersilia savignyi (bark spider) on Diospyros ebenum. (I) Xenobolus carnifex (Millipedes) in Garcinia spicata. (J) Holes made by Xylocopa sp. in Lepisanthes tetraphylla. (K) Indarbela quadrinotata in Lepisanthes tetraphylla. (L) Bark spider and juvenile scorpion on Albizia amara bark. 


\section{Data collection}

Bark traits of a total of 105 woody species (60 trees and 45 lianas) of tropical dry evergreen forest and faunal occurrence on them were studied in 2012 to 2014 (Appendix 1, Fig. 1). A minimum of 2 to 4 individuals for each species (for rare and sub-dominant species) to a maximum of 10 individuals (for dominant species) were sampled for all trees $(\geq 10 \mathrm{~cm}$ girth at breast height) and lianas $(\geq 3.1 \mathrm{~cm}$ girth measured at $130 \mathrm{~cm}$ from the rooting point). The sampling involved measurement of girth and removal of a piece of bark $\left(3 \mathrm{~cm}^{2}\right)$ of trees and lianas from the base of the stem, for avoiding thorns and other protuberance point. Bark of woody species was sampled for a total of 605 individuals of trees and lianas, from which totally 2420 bark samples were taken. Bark texture and surface were visually assessed in the field and bark thickness was measured using digital Vernier caliper to the nearest of $0 \cdot 1 \mathrm{~mm}$. The term 'bark' is often loosely used to describe everything external to the wood, for because in practice it is difficult to measure thickness of each individual layer of bark. Hence, the thickness reported here is a gross measure of all tissues external to wood. We applied the criteria of Whitmore (1962) and Yunus et al. (1990) to characterise bark traits. The occurrence of exudations like gums, resins and latex as shown by the liquid exuding from the localized zones of the cut bark as well as older injuries, was also recorded in the field. The nature of the exudation was also confirmed by referring to the available literature (Troup 1921, Council for Scientific \& Industrial Research 1956-
66, Gamble and Fischer, 1915-35). The major bark resource users as tree nesters and the wood boring xylovores were collected (for identification) in vials containing $80 \%$ ethanol and in addition captured in photos and videos in bark habitat or while they were feeding on them. Bark was removed and holes in the wood also investigated for the presence of faunal group and they were collected by net traps, hand picking or bottle traps. Fauna were identified by using various field guides and available literature (Alagesan and Ramanathan, 2013; Mishra, 1991).

\section{Results}

\section{Variation in bark thickness}

Bark thickness of 105 woody plant species (60 trees and 45 liana species) of Indian tropical dry evergreen forest ranged from 0.01 to $2.23 \pm 0.22 \mathrm{~cm}$ for the total of 2420 bark samples obtained from 605 individuals (Appendix 1). Bark thickness of the 60 tree species (stem circumference range 6 to $241.2 \mathrm{~cm}$ ) varied from 0.02 to $2.23 \pm 0.22 \mathrm{~cm}$ and those of lianas (stem circumference range 3.1 to 45.7 $\mathrm{cm}$ ) varied from 0.01 to $1.23 \pm 0.02 \mathrm{~cm}$. Among the 60 tree species the mean bark thickness was maximum for the evergreen species Garcinia spicata $(1.63 \mathrm{~cm})$ and least for the deciduous species Gmelina asiatica $(0.02 \mathrm{~cm})$. Among the 45 liana species the mean bark thickness was maximum for the thorny straggler Plecospermum spinosum $(0.83 \mathrm{~cm})$ and least $(0.01 \mathrm{~cm})$ for the tendril climber Cissus quadrangularis (Appendix 1).

Table 1. Bark faunal diversity in tropical dry evergreen forest on the Coromandel Coast of India.

\begin{tabular}{|c|c|c|c|}
\hline Life-style & Faunal group & Family & Species \\
\hline \multirow[t]{8}{*}{ Tree nesters } & Termites & Kalotermitidae & Cryptotermes sp. \\
\hline & Ants & Formicidae & $\begin{array}{l}\text { Camponotus sp. } \\
\text { Oecophylla samaragdina }\end{array}$ \\
\hline & Wasps & Vespidae & Polistes sp. \\
\hline & Bees & Apidae & Apis florea \\
\hline & Spiders & Hersiliidae & $\begin{array}{l}\text { Xylocopa } \text { sp. } \\
\text { Hersilia savignyi } \\
\text { Poecilothemia regalis } \\
\text { Poecilothemia striata } \\
\text { Herennia ornatissima }\end{array}$ \\
\hline & Scorpions & Buthidae & Mesobuthus tamulus * \\
\hline & & Scorpionoidea & Heterometrus flavimanus* \\
\hline & Millipedes & Pachybolidae & Xenobolus carnifex \\
\hline \multirow[t]{5}{*}{ Wood borers } & Termites & Kalotermitidae & Cryptotermes sp. \\
\hline & Jewel beetle & Buperestidae & Sternocera chrysis \\
\hline & Longhorn beetles & Cerambycidae & Unknown sp. \\
\hline & Carpenter bees & Apidae & Xуlocopa $\mathrm{sp}$. \\
\hline & Larvae & Cossidae & Indarbela quadrinotata \\
\hline
\end{tabular}

* Juvenile 


\section{Bark trait, sap feature and faunal assemblage}

In Indian tropical dry evergreen forest, the most common bark texture was rough $(51.42 \%)$ with deep fissures (72\%) (Appendix 1). About $28.57 \%$ of species had slightly rough bark followed by smooth texture $(20 \%)$. Of the total 105 species studied, 22 species possessed sap and among them the predominant (50\%) sap type was latex, followed by resin (31.8\%) and gum $(18.2 \%)$. The most common sap colour was milky white (41\%) and other colours include red, black, yellow and watery (Appendix 1). A total of thirteen species of tree nesters and five species of wood borers were observed in the tropical dry evergreen forest (Table 1). Among the fauna recorded from the 105 woody species, the most common bark resource users were termites, which utilised $32(30.47 \%)$ of the plant species followed by ants and millipedes (Appendix 1). The association between bark traits and faunal occurrence was analysed with principal component analysis (PCA). The first PCA axis explained $32.5 \%$ of the variation and it shows a trade-off between bark thickness, girth and faunal occurrence on the left vs. texture and fissure of bark on the right (Fig. 2). The second PCA axis explained $17.6 \%$ of the variation and shows a trade-off between faunal occurrence and bark texture at the top of the second PCA axis vs. stem girth and thickness of bark at the bottom. The same relationships and trade-offs were obtained with bivariate Pearson correlation (Table 2), for various faunal groups:

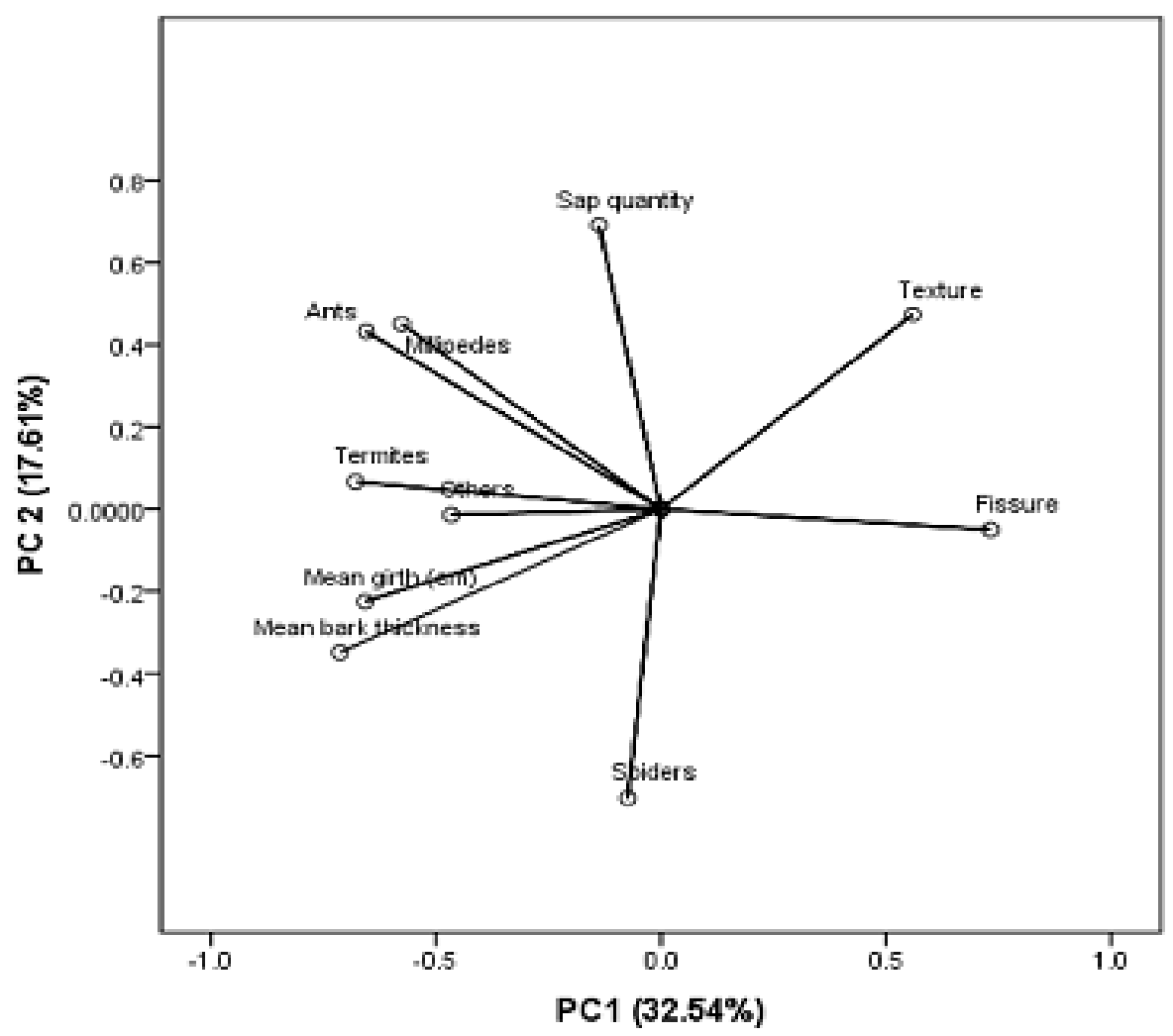

Fig. 2: Principal component analysis of wood and bark traits. The first two principal components explained $50.16 \%$ of observed variation.

Termite: We found a negative relationship of termite attack with evergreen species and a positive relationship with deciduous species. Bark thickness and texture (rough and deeply fissured) play a positive role in accommodating termites. Smooth and 'entire' type of bark provides resistance to termite attack (Table 2).

Ant: Bark thickness, sap quantity (scanty) and texture of deeply fissured type play a positive role in accommodating ant fauna. A weak positive relationship was obtained between rough bark and ant fauna. Whereas a negative relationship existed between 'entire' (non-fissured) bark type and ant fauna (Table 2).

Millipede: There is a positive relationship between stem girth and deeply fissured bark for millipede habitat and a negative relationship existed with 'entire' bark type and millipedes (Table 2). 


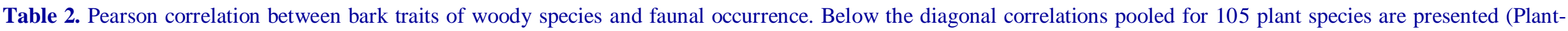

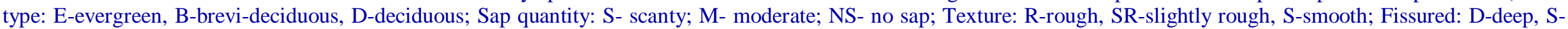
shallow, E-entire).

\begin{tabular}{|c|c|c|c|c|c|c|c|c|c|c|c|c|c|c|}
\hline Faunal group & $\mathbf{E}$ & B & D & $\begin{array}{l}\text { Mean } \\
\text { girth }\end{array}$ & $\begin{array}{l}\text { Mean } \\
\text { thickness }\end{array}$ & NS & Sca & Mod & $\mathbf{S}$ & SR & $\mathbf{R}$ & DF & SF & $\mathbf{E}$ \\
\hline Termite & $-0.220^{*}$ & 0.083 & $0.193^{*}$ & $0.208^{*}$ & $\underline{0.366^{* * *}}$ & 0.101 & -0.003 & -0.123 & $-0.228^{*}$ & -0.144 & $\underline{0.312^{* *}}$ & $\underline{0.439} 9^{* * *}$ & 0.045 & $-0.325^{* * *}$ \\
\hline Ants & -0.117 & 0.108 & 0.032 & 0.185 & $\underline{0.301^{* *}}$ & -0.123 & $\underline{0.265^{* * *}}$ & -0.082 & -0.121 & -0.167 & $0.248^{*}$ & $\underline{0.396}{ }^{* *}$ & -0.043 & $-0.215^{*}$ \\
\hline Millipedes & -0.063 & 0.069 & 0.006 & $0.195^{*}$ & 0.073 & 0.045 & 0.122 & -0.165 & -0.090 & -0.106 & 0.168 & $\underline{0.338^{* *}}$ & 0.009 & $-0.229^{*}$ \\
\hline Spider & 0.012 & -0.067 & 0.059 & 0.081 & 0.175 & $\underline{-0.290^{* *}}$ & -0.023 & $\underline{0.385^{* *}}$ & -0.116 & -0.174 & $0.250^{*}$ & 0.094 & 0.033 & -0.083 \\
\hline Scorpion & -0.028 & -0.076 & 0.121 & -0.022 & -0.052 & 0.074 & -0.045 & -0.052 & 0.105 & -0.088 & -0.004 & 0.142 & -0.101 & 0.001 \\
\hline Larvae & -0.041 & 0.010 & 0.041 & $0.199^{*}$ & $\underline{0.322^{* *}}$ & -0.015 & -0.065 & 0.076 & -0.100 & -0.126 & 0.193* & $\underline{0.345^{* *}}$ & -0.039 & $-0.197^{*}$ \\
\hline Wasp & -0.028 & 0.090 & -0.063 & 0.047 & -0.004 & 0.074 & -0.045 & -0.052 & -0.070 & 0.066 & -0.004 & -0.057 & 0.046 & 0.001 \\
\hline Bee & 0.114 & -0.076 & -0.063 & $0.248^{*}$ & $\underline{0.441^{* *}}$ & -0.095 & -0.045 & 0.159 & -0.070 & -0.088 & 0.135 & -0.057 & 0.046 & 0.001 \\
\hline Beetle & 0.023 & -0.093 & 0.074 & $0.194^{*}$ & 0.102 & 0.091 & -0.056 & -0.064 & 0.057 & -0.108 & 0.052 & $\underline{0.257^{* *}}$ & -0.124 & -0.056 \\
\hline
\end{tabular}

Significant correlations $(p<0.05)$ are given in bold and correlations with $p<0.001$ are in bold and underlined.

Table 3. Jaccard similarity index of bark faunal diversity and co-occurrence in tropical dry evergreen forest on the Coromandel Coast of India.

\begin{tabular}{|c|c|c|c|c|c|c|c|c|c|}
\hline & Termite & Ant & Millipede & Spider & Scorpion & Larva & Wasp & Bee & Beetle \\
\hline Termite & & 62.069 & 48.9796 & 22.2222 & 11.7647 & 22.2222 & 11.7647 & 11.7647 & 11.4286 \\
\hline Ant & & & 65.1163 & 5.1282 & 7.1429 & 26.6667 & 7.1429 & 14.2857 & 6.8966 \\
\hline Millipede & & & & 13.3333 & 0 & 19.0476 & 10.5263 & 10.5263 & 20 \\
\hline Spider & & & & & 0 & 0 & 0 & 0 & 12.5 \\
\hline Scorpion & & & & & & 33.3333 & 0 & 0 & 0 \\
\hline Larva & & & & & & & 0 & 33.3333 & 28.5714 \\
\hline Wasp & & & & & & & & 50 & 0 \\
\hline Bee & & & & & & & & & 0 \\
\hline Beetle & & & & & & & & & \\
\hline
\end{tabular}


Spider: Spider fauna show a strong positive relationship with sap producing plant species and an opposite trend with sap-lacking species. There is also a positive relationship with rough- surfaced bark for accommodating spider fauna (Table 2).

Others: Beetle larvae and bees show a positive relationship with stem girth and bark thickness. Further, beetles and beetle larvae show a positive relationship with deeply fissured bark, and larvae show a negative relationship with 'entire' bark. There is no significant relationship between bark traits and other faunal groups (scorpion and wasp). Evidently, bark texture, fissure and thickness play a positive role in accommodating faunal group in tropical dry evergreen forest.

Bark faunal diversity and their co-occurrence: Wood boring insects were prevalent in tropical dry evergreen forest (Table 1). The major bark resource users as tree nesters include termites, ants, wasps, bees, scorpions, and millipedes. The wood boring xylovores include beetle larvae, lepidopteron larvae, carpenter bees and beetles. The co-occurrence among bark faunal groups is also evident (Table 3). The highest values of co-occurrence were recorded for ants - millipedes and termites - ants and to lesser extent between termites - scorpions, termites - bees and termites - wasp.

\section{Discussion}

Many factors are related to bark thickness including species in question, position along the stem, tree health, fire history, etc. (Gill, 1995). In this study, bark thickness was positively related to stem diameter for all species. A comparison of bark thickness of various tropical forests revealed that the bark thickness of woody species of Indian tropical dry evergreen forest is lesser than those reported in other forests: the mean bark thickness of woody species is $0.30 \mathrm{~cm}$ in tropical dry evergreen forest is about five to six fold less than those of Bolivian savannah species (1.44 cm; Pinard and Huffman, 1997) and other inland forests in India $(1.80 \mathrm{~cm}$; Yunus et al., 1990).

The relatively high humidity coupled with the absence of fire incidence in Indian tropical dry evergreen forest (TDEF) would not have provided any trigger for developing greater bark thickness. The positive relationship obtained between stem size class and trunk bark thickness can be attributed to its natural defensive role. In TDEF, bark thickness showed no relationship with sap quantity, but we observed a significant relation between sap quantity and faunal habitation, mostly accommodating spiders.

Tree species rich in anti-feedants such as gum, resin, tannin and lignin are often relatively resistant and furthermore, investment in certain chemical defence such as latex can lead to specialisation by certain herbivorous taxa (Tavakilian et al., 1997) as exemplified by termites (Cryptotermes sp.) attack in Garcinia spicata, Ficus benghalensis, Manilkara hexandra, Mimusops elengi and Pterospermum canescens in our study sites (Appendix 1). Dry wood termites live entirely within the wood, do not need to maintain a connection with the ground or soil and do not absolutely require free water, but some species such as C. brevis will not survive under conditions of high humidity or water content in wood (Collins, 1969). Dry wood termites can invade live trees by attacking their bark which could degrade the value of timber species where dry wood termites live. There is a certain degree of host specificity in termite and about 73 plant species claimed resistance to termite attack. Bark texture plays a major role in accommodating various fauna in our study and rough bark provides good shelter for various fauna except for three families (Capparaceae, Verbenaceae and Vitaceae). Thus, biotic and abiotic threats seem to be the most important factors shaping bark thickness, chiefly for defensive function.

Bark must simultaneously perform many functions; no single function emerges as dominant influence on thickness. Plant traits play a major role in faunal diversity. Thicker barked and fissured plants become a habitat for tree nesters and wood borers. Barks hollowed by the wood borers are also used as nest sites by ants (as food source), spiders (as a prey site) and millipedes (as refuge or shelter). The Oecophylla samaragdina workers are also particularly effective in hunting insects that feed on the tissue and sap of tree (Bharti and Silla, 2011). Millipedes constitute one of the major groups of soil and litter fauna in tropical and temperate environments; they play an important role in energy flow and circulation of minerals in terrestrial ecosystems (Alagesan and Muthukrishnan, 2005). Xenobolus carnifex feeds exclusively on dead and decaying vegetation and also use their thicker bark as shelter. It should also be noted that there are other various potential functions that the bark plays. In our study we found the ecological use of bark as a resource for space and food by various fauna: woodfeeding insects attack live trees, which in turn create widespread disturbances in the forest (Schowalter, 2000). Wood borer damage meristem and shoots which may severely alter a plant's form (Whitham and Mopper, 
1985; Schowalter, 2000). The bark caterpillar, Indarbela quadrinotata attacks a variety of tree species in TDEF. Specialised conditions are required for the establishment of wood borers (Mishra, 1991); in our observation it mainly attacks older trees having thicker bark like Garcinia spicata and Lepisanthes tetraphylla. Among various factors, bark thickness of the tree is also important. The history of such damage can be inferred from tree shape and other enduring evidences on branches and boles like feeding galleries, exit holes, and tannin stains (Oliver and Larson, 1996). On the ecosystem level, wood borers potentially impact nutrient cycling process by altering both the quantity and quality of the litter (Feller, 2002). Furthermore, wood borers such as termites (Isopteran), jewel beetles (Buperestidae), longhorn beetles (Cerambycidae) and carpenter bees (Xylocopidae) in tropical dry evergreen forest provide habitat for many species of ants (Formicidae), wasp (Vespidae), bees (Apidae) and other arthropods. Results from various studies suggest that primary consumption level of wood boring insects may also modify forest dynamics and nutrient cycling process. These data suggest that barks play an important role in TDEF by providing suitable habitat for wood borers and numerous tree nesters.

In this study the highest values of co-occurrence were recorded for ants - millipedes because some millipedes form mutually beneficial relationship with ants or termites. The insect protect them from predators and the millipedes perform housekeeping duties for them by eating fungi and detritus in their nests. The most constant and widespread enemies of termites are ants and so the termite - ant association is also high in TDEF. Termites are very weak and fragile and this can be easily overpowered by ants and other predators, and they block off the entry tunnels by using their jaws or chemical weaponry as a formidable defence (Dejean and Feneron 1999). Ants and termites are eusocial insects that live in extended colonies and have a significant influence on the surrounding ecosystem. Termites feed on detritus material and thus play a major role in decomposition processes, nutrient cycling and carbon processing (Eggleton et al., 1997; Jones and Eggleton, 2000). Bark as a habitat with its hard dead tissue on live tree species, reduces as such the palatability to many fauna, but supports as a habitat particularly those species which harbour rough and fissured bark. All these together account for low bark faunal diversity recorded in the TDEF. The termites (with their innate ability to digest hard tissues) have an advantage in utilizing bark as food and habitat than other faunal groups.

\section{Conclusion}

This study investigated the functional aspects of bark as habitat and food source for faunal groups in the understudied tropical dry evergreen forest (TDEF) of India and such baseline research on plant resource use by animal communities will be valuable in understanding the complex forest biotic interactions useful for conservation of this and similar tropical forests. The tropical dry evergreen forest has a restricted geographical distribution and one of the world's low diversity forests, but subjected to various anthropogenic disturbances. This calls for greater attention to preserve the remaining patches of this forest type to save the biodiversity with the involvement of local people. Yet, the tropical dry evergreen forest supports a rich insect and avifauna, many of which help in forest ecosystem functioning (pollination and seed dispersal etc.) of tropical dry evergreen forest. This region's characteristic flora is not only a shelter for faunal community, but also has a rich cultural tradition associated with it as the TDEF sites are also the sacred groves. Therefore, we recommend a community-level approach for forest conservation with the involvement of local people and it is important that the local inhabitants realize the values of these patches of forest and make low levels of resource use from the forest.

\section{Conflict of interest statement}

Authors declare that they have no conflict of interest.

\section{Acknowledgement}

K. Anil thanks Pondicherry University for financial support received through UGC University fellowship.

\section{References}

Agee, J. K., 1993. Fire ecology of Pacific Northwest forests.Island Press, Washington DC.490 p.

Alagesan, P., Muthukrishnan, J., 2005. Bioenergetics of the household millipede pest, Xenobolus carnifex (Fabricius, 1775) (Diplopoda: Spirobolida). Peckiana 4, 3-14.

Alagesan, P., Ramanathan, B., 2013. Diversity of Millipedes in Alagar Hills Reserve Forest in Tamil Nadu, India. Int. J. Biodiv. Article ID 715460, 5 p. http://dx.doi.org/10.1155/ 2013/715460.

Amman, G. D., 1977. The role of the mountain pine beetle in lodge pole pine ecosystems: impact on succession. In: The Role of Arthropods in Forest Ecosystems (Ed.: Mattson, W. J.). Springer, Berlin. pp.3-18.

Barbosa, P., Wagner, M. R., 1989. Introduction to Forest and Shade Tree Insects. Academic Press Inc., San Diego. 
Bharti, H.,Silla, S., 2011. Notes on life history of Oecophylla smaragdina (Fabricius) and its potential as biological control agent. Halteres 3, 57-64.

Champion, H. G., Seth, S.K., 1968. A Revised Survey of the Forest Types of India. Govt. of India Press, Delhi.

Coimbra-Filho, A. F., Mittermeier, R. A., 1976. Exudateeating and tree-gouging in marmosets. Nature 262, 630.

Collins, M. S., 1969. Water relations in termites. In: Biology of Termites (Eds.: Krishna, K., Weesner, F. M.). Vol. I. Academic Press, New York. pp.433-458.

Council for Scientific and Industrial Research. 1956-66. The Wealth of India, Raw Materials. CSIR, New Delhi.

Cramer, M.B., 1975. Corticolous lichens of riparian deciduous trees in the central Front Range of Colorado. Bryologist 78, 44-56.

Dejean, A., Feneron, R. 1999. Predatory behaviour in the ponerine ant, Centromyrmex bequaerti: a case of termitolesty. Behav. Processes. 47, 125-133.

Eberhardt, L. S. 2000. Use and selection of sap trees by yellow-bellied sapsuckers. The Auk. 117, 41-51.

Eggleton, P., Homathevi, R., Jeeva, D., Jones, D.T., Davies, R.G., Maryati, M., 1997. The species richness and composition of termites (Isoptera) in primary and regenerating lowland dipterocarp forest in Sabah, East Malaysia. Ecotropica. 3, 119-128.

Evert, R., Esau, K., Eichhorn, S. 2006. Esau's Plant Anatomy: Meristems, Cells, and Tissue of the Plant Body: Their structure, Function, and Development. Wiley-Liss, Hoboken, New Jersey.

Feller, I. C., 2002. The role of herbivory by wood-boring insects in mangrove ecosystems in Belize. Oikos. 97, 167176.

Feller, I. C., Mathis, W. N., 1997. Primary Herbivory by Wood-Boring Insects along an Architectural Gradient of Rhizophora mangle. Biotropica. 29, 440-451.

Ferrenberg, S., Mitton, J. B., 2014. Smooth bark surfaces can defend trees against insect attack: resurrecting a 'slippery' hypothesis. Funct. Ecol. 28(4), 837-845.

Gamble, J. S., Fischer, C. E. C., 1915-1935. Flora of the Presidency of Madras. Vols. I-III, Adlard \& Son., London.

Gill, A. M., 1995. Stem and fire. Plant Stems: Physiology and Functional Morphology (Ed.: Gartner, B. L.). Academic Press, San Diego. pp.323-342.

Gorman, M. W., 1989. Eastern part of Washington Forest Reserve. USDA Geological survey, $19^{\text {th }}$ annual report, Part V: Forest Reserves. Government Printing Office, Washington DC. pp.315- 350.

Grijpma, P., 1970. Studies on the shoot borer Hypsipyla grandella (Zeller) Lep. Pyralidae.Vol 1. Miscellaneous Publications No. 101. Institutio Interamericado de CienciasAgricolas. Turrialba, Costa Rica.

Grijpma, P., Gara, R. I., 1970. Studies on the shoot borer Hypsipyla grandella Zeller. I. Host selection behavior. Turrialba. 20, 233-240.

Harmon, M. E., 1984. Survival of trees after low-intensity surface fires in Great Smoky Mountains National Park. Ecology. 65, 796-802.
Hegde, V., Chandran, M. D. S., Gadgil, M., 1998. Variation in bark thickness in a tropical forest community of Western Ghats in India. Funct. Ecol. 12, 313-318.

Howard, F. W., 1991. Seasonal incidence of shoot infestation by mahogany shoot borer (Lepidoptera: Phycitidae) in Florida. Florida Entomol. 74, 150-151.

Jacobs, M., 1988. The Tropical Rain Forest. A First Encounter. Springer-Verlag, Berlin.

Jones, D.T., Eggleton, P., 2000. Sampling termite assemblages in tropical forests: testing a rapid biodiversity assessment protocol. J. Appl. Ecol. 37, 191-203.

Levin, D. A., 1976. Alkaloid-bearing plants: an ecogeographic perspective. Amer. Nat. 110, 261-284.

Lundquist, J. E., 2000. A method of estimating direct and indirect effects of Armillaria root disease and other smallscale forest disturbances on canopy gap size. For. Sci. 46, 356-362.

Mani, S., Parthasarathy, N., 2006. Tree diversity and stand structure in inland and coastal tropical dry evergreen forests of peninsular India. Curr. Sci. 90, 1238-1246.

Meher-Homji, V. M., 1974. On the origin of tropical dry evergreen forest of south India. Int. J. Ecol. Env. Sci. 1, 19-39.

Mishra, S.C., 1991. Effect of temperature and relative humidity on consumption and digestion of food (bark) by larvae of Indarbela quadrinotata Wlk. (Lepidoptera: Indarbelidae). J. Entomol. Res. Soc. 15, 287-293.

Oliver, C. D., Larson, B. C., 1996. Forest Stand Dynamics. John Wiley and Sons, New York.

Paine, C. E. T., Stahl, C., Courtois, E. A., Patiño, S., Sarmiento, C., Baraloto, C., 2010. Functional explanations for variation in bark thickness in tropical rain forest trees. Funct. Ecol. 24, 1202-1210.

Parthasarathy, N., Selwyn, M.A., Udayakumar, M., 2008. Tropical dry evergreen forests of peninsular India: ecology and conservation significance. Trop. Conserv. Sci. 1, 89110.

Pinard, M. A., Huffman, J., 1997. Fire resistance and bark properties of trees in a seasonally dry forest in eastern Bolivia. J. Trop. Ecol. 13, 727-740.

Poorter, L., McNeil, A., Hurtado, V., Prins, H. T., Putz, F. E., 2014. Bark traits and life-history strategies of tropical dryand moist forest trees. Funct. Ecol. 28, 232-242.

Romberger, J. A., Hejnowicz, Z., Hill, J. F., 1992. Plant Structure, Function and Development. Springer-Verlag, Berlin.

Romero, C., 2013. Bark: structure and functional ecology. Bark: Use, Management, and Commerce in Africa (Eds.: Cunningham, A. B., Campbell, B. M., Luckert, M. K.). Advances in Economic Botany, 17. The New York Botanical Garden Press, Bronx. pp.5-25.

Schowalter, T. D., 1981. Insect herbivore relationship to the state of the host plant: biotic regulation of ecosystem nutrient cycling through ecological succession. Oikos. 37, 126-130.

Schowalter, T. D., 2000. Insect Ecology: An Ecosystem Approach. Academic Press, Orlando. 
Stephenson, S.L., 1989. Distribution and ecology of myxomycetes in temperate forests. II. Patterns of occurrence on bark surface of living trees, leaf litter, and dung. Mycologia. 81, 608-621.

Tavakilian, G., Berkov, A., Meurer-Grimes, B., Mori, S., 1997. Neotropical tree species and their faunas of Xylophagous longicorns (Coleoptera: Cerambycidae) in French Guiana. Bot. Rev. 63, 303-355.

Troup, R. S., 1921. The Silviculture of Indian Trees. Clarendon Press, Oxford.

Vines, R. G., 1968. Heat transfer through bark and the resistance of trees to fire. Aust. J. Bot. 16, 499-514.

Whitham, T. G., Mopper, S., 1985. Chronic herbivory: impacts on architecture and sex expression of pinyon pine. Science 228, 1089-1091.
Whitmore, T. C., 1962. Studies in systematic bark morphology I. Bark morphology in Dipterocarpaceae. New Phytol. 61, 191.

Wilson, B. G., Witkowski, E. T. F., 2003. Seed banks, bark thickness and change in age and size structure (19781999) of the African savanna tree, Burkeaafricana. Plant Ecol. 167, 151-162.

Yamazaki, S., Ikeda, T., Taketani, A., Vasquez Pacheco, C.Sato, T., 1992. Attack by the mahogany shoot borer, Hypsipyla grandella Zeller (Lepidoptera: Pyralidae), on the Meliaceous trees in the Peruvian Amazon. Appl. Entomol. Zool. 27, 31-38.

Yunus, M., Yunus, D., Iqbal, M., 1990. Systematic bark morphology of some tropical trees. Bot. J. Linn. Soc. 103, $367-377$.

APPENDIX I. : Bark traits and resource use by faunal community in tropical dry evergreen forest on the Coromandel Coast of India (Lf- Life-form : T- tree, L - liana; Plant-type: E-evergreen, B-brevi-deciduous, D-deciduous; Sap quantity: S- scanty; M- moderate; NS- no sap; Texture: R-rough, SR-slightly rough, S-smooth; Sap colour: M-milky, Wwatery, Y-yellow, R-red, NA-not applicable; Fissured: D-deep, Di-dippled, S-smooth, E-entire; Bark fauna: Tetermite, La- larvae, Bt- beetle, An- ants, Wa- wasp, Be- bee, Sp- spider, Sc- scorpion, Mi- Millipede). 


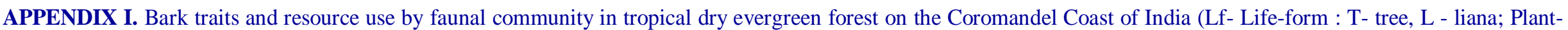

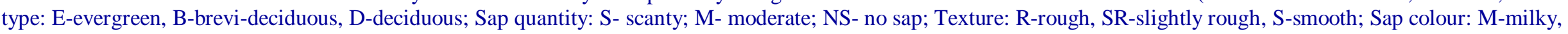

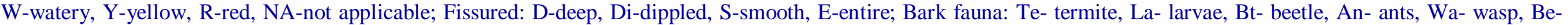
bee, Sp- spider, Sc- scorpion, Mi- Millipede).

\begin{tabular}{|c|c|c|c|c|c|c|c|c|c|c|c|}
\hline \multirow{2}{*}{$\begin{array}{l}\text { Sl. } \\
\text { no. }\end{array}$} & \multirow{2}{*}{ Plant species } & \multirow{2}{*}{ Family } & \multirow{2}{*}{$\begin{array}{l}\text { Plant } \\
\text { type }\end{array}$} & \multirow{2}{*}{$\begin{array}{l}\text { Sampl } \\
\text { e size }\end{array}$} & \multirow{2}{*}{$\begin{array}{l}\text { Mean } \\
\text { girth } \\
(\mathrm{cm})\end{array}$} & \multirow{2}{*}{$\begin{array}{l}\text { Mean } \\
\text { bark } \\
\text { thickness } \\
(\mathrm{cm})\end{array}$} & \multirow{2}{*}{$\begin{array}{l}\text { Sap } \\
\text { quantity }\end{array}$} & \multirow{2}{*}{$\begin{array}{l}\text { Texture } \\
\text { R/SR/S }\end{array}$} & \multirow{2}{*}{$\begin{array}{l}\text { Sap colour } \\
\text { M/W/Y/N/R }\end{array}$} & \multirow{2}{*}{$\begin{array}{l}\text { Fissure } \\
\text { D/Di/S/E }\end{array}$} & \multirow[t]{2}{*}{ Fauna } \\
\hline & & & & & & & & & & & \\
\hline & Trees & & & & & & & & & & \\
\hline 1 & Aglaia elaeagnoidea (Juss.) Benth. & Meliaceae & $\mathrm{E}$ & 4 & 85.3 & 0.15 & NS & $\mathrm{R}$ & NA & $\mathrm{S}$ & \\
\hline 2 & Albizia amara (Roxb.) Boivin & Mimosaceae & $\mathrm{D}$ & 10 & 60.26 & 0.26 & NS & $\mathrm{R}$ & NA & $\mathrm{D}$ & $\mathrm{Te}, \mathrm{An}, \mathrm{Sc}, \mathrm{La}$ \\
\hline 3 & Albizia lebbeck (L.) Benth. & Mimosaceae & $\mathrm{D}$ & 4 & 114.2 & 0.42 & NS & $\mathrm{R}$ & NA & $\mathrm{D}$ & $\mathrm{Te}, \mathrm{Bt}, \mathrm{Sp}, \mathrm{Mi}$ \\
\hline 4 & Allophyllus serratus (Roxb.) Kurz. & Sapindaceae & $\mathrm{E}$ & 4 & 114.2 & 0.13 & NS & $\mathrm{S}$ & NA & $\mathrm{E}$ & \\
\hline 5 & Atalantia monophylla (L.) Correa & Rutaceae & $\mathrm{E}$ & 8 & 39.18 & 0.26 & NS & $\mathrm{R}$ & NA & $\mathrm{S}$ & $\mathrm{Te}, \mathrm{Mi}$ \\
\hline 6 & Azadirachta indica A. Juss. & Meliaceae & $\mathrm{B}$ & 5 & 59 & 0.331 & NS & $\mathrm{R}$ & NA & $\mathrm{S}$ & \\
\hline 7 & Barringtonia acutangula (L.) Gaertner & Barringtoniaceae & $\mathrm{E}$ & 4 & 92.4 & 0.35 & NS & $\mathrm{S}$ & NA & $\mathrm{E}$ & $\mathrm{Bt}$ \\
\hline 8 & Bauhinia racemosa Lam. & Caesalpiniaceae & $\mathrm{D}$ & 4 & 33.6 & 0.12 & NS & SR & NA & $\mathrm{S}$ & $\mathrm{Te}, \mathrm{Mi}$ \\
\hline 9 & Benkara malabarica (Lam.) Tirven. & Rubiaceae & $\mathrm{E}$ & 4 & 16.2 & 0.1 & NS & SR & NA & $\mathrm{E}$ & \\
\hline 10 & Breynia vitis-idaea (Burm. f.) Fischer & Euphorbiaceae & $\mathrm{E}$ & 4 & 44.7 & 0.13 & NS & SR & NA & $\mathrm{Di}$ & \\
\hline 11 & Butea monosperma (Lam.) Taubert & Papilionaceae & $\mathrm{D}$ & 4 & 98.3 & 0.86 & NS & $\mathrm{R}$ & NA & $\mathrm{D}$ & $\mathrm{Te}$ \\
\hline 12 & Calophyllum inophyllum L. & Clusiaceae & $\mathrm{E}$ & 4 & 73.1 & 0.16 & M & $\mathrm{R}$ & $\mathrm{M}$ & $\mathrm{S}$ & \\
\hline 13 & $\begin{array}{l}\text { Canthium dicoccum (Gaertn.) Teijsm. \& } \\
\text { Binn. }\end{array}$ & Rubiaceae & $\mathrm{E}$ & 10 & 38.64 & 0.4 & NS & $\mathrm{R}$ & NA & $\mathrm{S}$ & \\
\hline 14 & Cassia fistula $\mathrm{L}$ & Caesalpiniaceae & $\mathrm{D}$ & 4 & 34.6 & 0.32 & NS & $\mathrm{R}$ & NA & $\mathrm{S}$ & Te,An \\
\hline 15 & Chionanthus zeylanica $\mathrm{L}$. & Oleaceae & $\mathrm{E}$ & 10 & 40.9 & 0.26 & NS & $\mathrm{R}$ & NA & $\mathrm{S}$ & Mi, An \\
\hline 16 & Cordia obliqua Willd. & Cordiaceae & $\mathrm{B}$ & 4 & 63.1 & 0.31 & NS & $\mathrm{R}$ & NA & $\mathrm{S}$ & Te,An \\
\hline 17 & Crateva magna (Lour.) DC. & Capparaceae & $\mathrm{D}$ & 4 & 73.2 & 0.64 & NS & $\mathrm{S}$ & NA & $\mathrm{S}$ & \\
\hline 18 & Diospyros ebenum Koen & Ebenaceae & $\mathrm{E}$ & 10 & 46.7 & 0.3 & NS & $\mathrm{R}$ & NA & $\mathrm{S}$ & $\mathrm{Te}, \mathrm{An}, \mathrm{Mi}, \mathrm{Sp}$ \\
\hline 19 & Diospyros ferrea (Wild.) Bakh & Ebenaceae & $\mathrm{E}$ & 4 & 47.6 & 0.24 & NS & $\mathrm{R}$ & NA & $\mathrm{S}$ & $\mathrm{Te}$ \\
\hline 20 & $\begin{array}{l}\text { Drypetes sepiaria (Wight and Arn.) Pax } \\
\text { and Hoffm. }\end{array}$ & Euphorbiaceae & $\mathrm{E}$ & 4 & 102.8 & 0.44 & NS & $\mathrm{R}$ & NA & $\mathrm{E}$ & $\begin{array}{l}\text { Te, An, Mi, } \\
\text { Wa, Be }\end{array}$ \\
\hline 21 & Ehretia pubescens Benth & Boraginaceae & $\mathrm{B}$ & 4 & 37.3 & 0.18 & NS & $\mathrm{R}$ & NA & $\mathrm{E}$ & \\
\hline 22 & Eugenia bracteata (Wild.) Roxb. & Moraceae & $\mathrm{E}$ & 4 & 33.9 & 0.14 & NS & $\mathrm{R}$ & NA & $\mathrm{S}$ & \\
\hline 23 & Ficus benghalensis L. & Moraceae & $\mathrm{B}$ & 4 & 149.9 & 0.29 & M & $\mathrm{R}$ & M & $\mathrm{E}$ & \\
\hline 24 & Ficus hispida L.f. & Moraceae & B & 4 & 62 & 0.2 & M & $\mathrm{R}$ & $\mathrm{M}$ & $\mathrm{E}$ & $\mathrm{Te}$ \\
\hline 25 & Ficus religiosa $\mathrm{L}$. & Moraceae & B & 4 & 241.2 & 0.64 & NS & $\mathrm{R}$ & NA & $\mathrm{E}$ & $\mathrm{Sp}$ \\
\hline 26 & Flacourtia indica (Burm.f.) Merr. & Flacourtiaceae & $\mathrm{B}$ & 4 & 23.6 & 0.17 & NS & SR & NA & $\mathrm{E}$ & \\
\hline 27 & $\begin{array}{l}\text { Garcinia spicata (Wight \& Arn.) J.D. } \\
\text { Hook. }\end{array}$ & Clusiaceae & $\mathrm{E}$ & 4 & 122.1 & 1.63 & M & $\mathrm{R}$ & $\mathrm{Y}$ & $\mathrm{S}$ & Te, La,An,Be \\
\hline 28 & Glycosmis mauritiana Yuich. Tanaka. & Rutaceae & $\mathrm{E}$ & 4 & 19.2 & 0.05 & NS & $\mathrm{S}$ & NA & $\mathrm{E}$ & \\
\hline 29 & Gmelina asiatica $\mathrm{L}$. & Verbenaceae & $\mathrm{E}$ & 4 & 29.1 & 0.02 & NS & $\mathrm{S}$ & NA & $\mathrm{E}$ & Mi, An \\
\hline 30 & Ixora pavetta T. Anderson & Rubiaceae & $\mathrm{E}$ & 4 & 49.4 & 0.46 & NS & $\mathrm{R}$ & NA & $\mathrm{S}$ & Mi, An \\
\hline 31 & Lannea coromandelica (Houtt.) Merr. & Anacardiaceae & $\mathrm{D}$ & 4 & 47.9 & 0.35 & M & $\mathrm{R}$ & NA & $\mathrm{S}$ & $\mathrm{Sp}$ \\
\hline 32 & Lepisanthes tetraphylla (Vahl.) Radlk. & Sapindaceae & $\mathrm{E}$ & 10 & 51.7 & 0.44 & NS & $\mathrm{R}$ & NA & $\mathrm{D}$ & $\begin{array}{l}\text { Te,An, La, } \\
\mathrm{Bt}, \mathrm{Mi}\end{array}$ \\
\hline
\end{tabular}




\begin{tabular}{|c|c|c|c|c|c|c|c|c|c|c|c|}
\hline \multirow{2}{*}{$\begin{array}{l}\text { Sl. } \\
\text { no. }\end{array}$} & \multirow{2}{*}{ Plant species } & \multirow{2}{*}{ Family } & \multirow{2}{*}{$\begin{array}{l}\text { Plant } \\
\text { type }\end{array}$} & \multirow{2}{*}{$\begin{array}{l}\text { Sampl } \\
\text { e size }\end{array}$} & \multirow{2}{*}{$\begin{array}{l}\text { Mean } \\
\text { girth } \\
(\mathrm{cm})\end{array}$} & \multirow{2}{*}{$\begin{array}{l}\text { Mean } \\
\text { bark } \\
\text { thickness } \\
(\mathrm{cm})\end{array}$} & \multirow{2}{*}{$\begin{array}{l}\text { Sap } \\
\text { quantity }\end{array}$} & \multirow{2}{*}{$\begin{array}{l}\text { Texture } \\
\text { R/SR/S }\end{array}$} & \multirow{2}{*}{$\begin{array}{l}\text { Sap colour } \\
\text { M/W/Y/N/R }\end{array}$} & \multirow{2}{*}{$\begin{array}{l}\text { Fissure } \\
\text { D/Di/S/E }\end{array}$} & \multirow[t]{2}{*}{ Fauna } \\
\hline & & & & & & & & & & & \\
\hline 33 & $\begin{array}{l}\text { Mallotus philippensis (Lam.) Muell.- } \\
\text { Arg. }\end{array}$ & Euphorbiaceae & $\mathrm{E}$ & 4 & 23.4 & 0.73 & NS & $\mathrm{R}$ & NA & $\mathrm{S}$ & Te, An \\
\hline 34 & Mallotus rhamnifolius Muell.-Arg. & Euphorbiaceae & $\mathrm{E}$ & 4 & 17.1 & 0.44 & NS & $\mathrm{S}$ & NA & $\mathrm{E}$ & \\
\hline 35 & Manilkara hexandra (Roxb.) Dubard & Sapotaceae & $\mathrm{B}$ & 4 & 86.1 & 0.2 & NS & $\mathrm{R}$ & NA & $\mathrm{D}$ & \\
\hline 36 & $\begin{array}{l}\text { Maytenus emarginata (Wild.) Ding } \\
\text { Hou. }\end{array}$ & Celastraceae & $\mathrm{E}$ & 4 & 25.2 & 0.05 & NS & $\mathrm{S}$ & NA & $\mathrm{S}$ & \\
\hline 37 & Memecylon umbellatum Burm.f. & Melastomataceae & $\mathrm{E}$ & 10 & 37.9 & 0.3 & NS & SR & NA & $\mathrm{S}$ & $\mathrm{Mi}, \mathrm{An}, \mathrm{Te}$ \\
\hline 38 & Mimusops elengi $\mathrm{L}$. & Sapotaceae & $\mathrm{E}$ & 4 & 55.3 & 0.61 & $\mathrm{~S}$ & $\mathrm{R}$ & M & $\mathrm{D}$ & $\mathrm{Te}, \mathrm{An}$ \\
\hline 39 & Morinda coreia Buch. -Ham. & Rubiaceae & $\mathrm{E}$ & 6 & 45.7 & 0.39 & NS & $\mathrm{R}$ & NA & $\mathrm{D}$ & $\mathrm{Te}, \mathrm{Sp}$ \\
\hline 40 & Morinda pubescesns Sm. & Rubiaceae & $\mathrm{B}$ & 4 & 21.2 & 0.06 & NS & SR & NA & $\mathrm{E}$ & $\mathrm{Te}$ \\
\hline 41 & Ochna obtusata DC. & Ochnaceae & $\mathrm{D}$ & 4 & 39.3 & 0.12 & NS & SR & NA & $\mathrm{E}$ & Te, An \\
\hline 42 & Pamburus missionis (Wight) Swingle & Rutaceae & $\mathrm{E}$ & 4 & 77.8 & 0.56 & NS & $\mathrm{R}$ & NA & $\mathrm{Di}$ & \\
\hline 43 & $\begin{array}{l}\text { Pleiospermium alatum (Wall. ex Wight. } \\
\text { \& Arn.) Swingle }\end{array}$ & Rutaceae & $\mathrm{E}$ & 4 & 55.2 & 0.17 & NS & $\mathrm{R}$ & NA & $\mathrm{E}$ & \\
\hline 44 & Pongamia pinnata $(\mathrm{L}$.$) Pierre$ & Papilionaceae & $\mathrm{B}$ & 4 & 63.4 & 0.24 & NS & SR & NA & $\mathrm{E}$ & \\
\hline 45 & Premna latifolia Roxb. & Verbenaceae & $\mathrm{E}$ & 4 & 97.3 & 0.75 & NS & $\mathrm{S}$ & NA & $\mathrm{E}$ & \\
\hline 46 & Pterospermum canescens Roxb. & Sterculiaceae & $\mathrm{B}$ & 10 & 42.5 & 0.29 & S & $\mathrm{R}$ & $\mathrm{R}$ & $\mathrm{D}$ & $\mathrm{Te}, \mathrm{An}, \mathrm{Mi}$ \\
\hline 47 & $\begin{array}{l}\text { Pterospermum xylocarpum (Gaertn.) } \\
\text { Sant. \& Wagh. }\end{array}$ & Sterculiaceae & $\mathrm{B}$ & 4 & 68.1 & 0.74 & $\mathrm{~S}$ & $\mathrm{R}$ & $\mathrm{R}$ & $\mathrm{D}$ & $\mathrm{Te}, \mathrm{An}$ \\
\hline 48 & Salvadora persica $\mathrm{L}$. & Salvadoraceae & $\mathrm{B}$ & 4 & 67.4 & 0.15 & NS & $\mathrm{S}$ & NA & $\mathrm{S}$ & \\
\hline 49 & Sapindus emarginatus Vahl & Sapindaceae & $\mathrm{B}$ & 4 & 89.2 & 0.29 & NS & $\mathrm{R}$ & NA & $\mathrm{D}$ & $\mathrm{Te}, \mathrm{An}, \mathrm{La}, \mathrm{Mi}$ \\
\hline 50 & $\begin{array}{l}\text { Securenega leucopyrus (Willd.) Muell.- } \\
\text { Arg. }\end{array}$ & Euphorbiaceae & $\mathrm{E}$ & 4 & 6 & 0.04 & NS & $\mathrm{S}$ & NA & $\mathrm{E}$ & \\
\hline 51 & Semecarpus anacardium L. f. & Anacardiaceae & $\mathrm{D}$ & 4 & 112.5 & 0.25 & M & SR & $\mathrm{B}$ & $\mathrm{S}$ & \\
\hline 52 & Streblus asper Lour. & Moraceae & $\mathrm{E}$ & 4 & 46 & 0.27 & $\mathrm{~S}$ & SR & M & $\mathrm{S}$ & \\
\hline 53 & Strychnos nux-vomica $\mathrm{L}$. & Loganiaceae & $\mathrm{D}$ & 4 & 37.4 & 0.16 & NS & $\mathrm{R}$ & NA & $\mathrm{S}$ & \\
\hline 54 & Syzygium cumini (L.) Skeels & Myrtaceae & $\mathrm{B}$ & 4 & 123.3 & 0.53 & $\mathrm{~S}$ & SR & NA & $\mathrm{D}$ & Mi, An \\
\hline 55 & Tamarindus indica $\mathrm{L}$. & Caesalpiniaceae & $\mathrm{B}$ & 4 & 82.1 & 0.81 & NS & $\mathrm{R}$ & NA & $\mathrm{D}$ & $\mathrm{Te}, \mathrm{Sp}$ \\
\hline 56 & $\begin{array}{l}\text { Tarenna asiatica }(L) \text { kuntz ex } \\
\text { Schumann. }\end{array}$ & Rubiaceae & $\mathrm{E}$ & 4 & 12.3 & 0.07 & NS & $\mathrm{S}$ & NA & $\mathrm{E}$ & \\
\hline 57 & Terminalia bellirica (Gaertn.) Roxb. & Combretaceae & $\mathrm{D}$ & 4 & 114.2 & 0.23 & NS & $\mathrm{R}$ & NA & $\mathrm{D}$ & $\mathrm{Te}, \mathrm{An}, \mathrm{Mi}$ \\
\hline 58 & $\begin{array}{l}\text { Tricalysia sphaerocarpa (Dalz.) } \\
\text { Gamble }\end{array}$ & Rubiaceae & $\mathrm{E}$ & 45 & 48.7 & 0.35 & NS & $\mathrm{S}$ & NA & $\mathrm{E}$ & $\mathrm{Te}, \mathrm{An}, \mathrm{Mi}$ \\
\hline 59 & Vitex altissima L.f. & Verbenaceae & $\mathrm{D}$ & 4 & 74.1 & 0.13 & NS & SR & NA & $\mathrm{S}$ & \\
\hline 60 & $\begin{array}{l}\text { Walsura trifolia (A. Juss.) Harms } \\
\text { Lianas }\end{array}$ & Meliaceae & $\mathrm{E}$ & 4 & 103.7 & 0.78 & NS & $\mathrm{R}$ & NA & $\mathrm{D}$ & Te, An \\
\hline 61 & Abrus precatorius $\mathrm{L}$. & Papilionaceae & $\mathrm{B}$ & 4 & 5 & 0.06 & NS & SR & NA & $\mathrm{S}$ & $\mathrm{Te}, \mathrm{Wa}$ \\
\hline 62 & Acacia caesia $($ L.) Willd. & Mimosaceae & $\mathrm{B}$ & 10 & 14.3 & 0.21 & NS & $\mathrm{R}$ & NA & $\mathrm{E}$ & $\mathrm{Te}, \mathrm{An}, \mathrm{Mi}$ \\
\hline 63 & $\begin{array}{l}\text { Ampelocissus tomentosa (Heyne ex } \\
\text { Roth) Planch. }\end{array}$ & Vitaceae & $\mathrm{B}$ & 2 & 5 & 0.1 & NS & SR & NA & $\mathrm{S}$ & \\
\hline 64 & Argyreia cymosa (Roxb.) Sweet & Convolvulaceae & $\mathrm{E}$ & 4 & 5 & 0.13 & $\mathrm{~S}$ & SR & M & $\mathrm{S}$ & $\mathrm{Sp}$ \\
\hline
\end{tabular}




\begin{tabular}{|c|c|c|c|c|c|c|c|c|c|c|c|}
\hline \multirow{2}{*}{$\begin{array}{l}\text { Sl. } \\
\text { no. }\end{array}$} & \multirow{2}{*}{ Plant species } & \multirow{2}{*}{ Family } & \multirow{2}{*}{$\begin{array}{l}\text { Plant } \\
\text { type }\end{array}$} & \multirow{2}{*}{$\begin{array}{l}\text { Sampl } \\
\text { e size }\end{array}$} & \multirow{2}{*}{$\begin{array}{l}\text { Mean } \\
\text { girth } \\
(\mathrm{cm})\end{array}$} & \multirow{2}{*}{$\begin{array}{l}\text { Mean } \\
\text { bark } \\
\text { thickness } \\
(\mathrm{cm})\end{array}$} & \multirow{2}{*}{$\begin{array}{l}\text { Sap } \\
\text { quantity }\end{array}$} & \multirow{2}{*}{$\begin{array}{l}\text { Texture } \\
\text { R/SR/S }\end{array}$} & \multirow{2}{*}{$\begin{array}{l}\text { Sap colour } \\
\text { M/W/Y/N/R }\end{array}$} & \multirow{2}{*}{$\begin{array}{l}\text { Fissure } \\
\text { D/Di/S/E }\end{array}$} & \multirow[t]{2}{*}{ Fauna } \\
\hline & & & & & & & & & & & \\
\hline 65 & Canavalia virosa (Roxb.) Wight \& Arn. & Papilionaceae & $\mathrm{D}$ & 4 & 3.9 & 0.07 & NS & SR & NA & $\mathrm{E}$ & $\mathrm{Te}$ \\
\hline 66 & Cansjera rheedii Gmel. & Opiliaceae & $\mathrm{E}$ & 4 & 14.3 & 0.17 & NS & $\mathrm{SR}$ & NA & $\mathrm{S}$ & \\
\hline 67 & Capparis brevispina DC. & Capparaceae & $\mathrm{E}$ & 10 & 10.7 & 0.15 & NS & $\mathrm{R}$ & NA & $\mathrm{S}$ & \\
\hline 68 & Capparis rotundifolia Rottl. & Capparaceae & $\mathrm{E}$ & 4 & 10.1 & 0.05 & NS & $\mathrm{S}$ & NA & $\mathrm{E}$ & \\
\hline 69 & Capparis sepiaria L. & Capparaceae & $\mathrm{E}$ & 4 & 13.7 & 0.14 & NS & $\mathrm{R}$ & NA & $\mathrm{S}$ & \\
\hline 70 & Capparis zeylanica $\mathrm{L}$. & Capparaceae & $\mathrm{E}$ & 4 & 21.3 & 0.16 & NS & $\mathrm{R}$ & NA & $\mathrm{S}$ & \\
\hline 71 & Carissa spinarum $\mathrm{L}$. & Apocynaceae & $\mathrm{E}$ & 10 & 6.9 & 0.09 & M & $\mathrm{R}$ & $\mathrm{M}$ & $\mathrm{E}$ & $\mathrm{Sp}$ \\
\hline 72 & $\begin{array}{l}\text { Cayratia pedata (Lam.) Juss. ex } \\
\text { Gagnep. }\end{array}$ & Vitaceae & $\mathrm{E}$ & 4 & 6.4 & 0.06 & NS & $\mathrm{S}$ & NA & $\mathrm{E}$ & \\
\hline 73 & $\begin{array}{l}\text { Cissampelos pareira L. var. hirsuta } \\
\text { (Buch.-Ham. ex DC.) Forman }\end{array}$ & Menispermaceae & $\mathrm{B}$ & 4 & 3.4 & 0.06 & M & SR & NA & $\mathrm{E}$ & \\
\hline 74 & Cissus quadrangularis $\mathrm{L}$. & Vitaceae & $\mathrm{E}$ & 10 & 4.1 & 0.01 & NS & SR & NA & $\mathrm{E}$ & \\
\hline 75 & Cissus vitiginea $\mathrm{L}$. & Vitaceae & $\mathrm{D}$ & 10 & 10.1 & 0.29 & NS & $\mathrm{R}$ & NA & $\mathrm{E}$ & \\
\hline 76 & Coccinia grandis (L.) Voigt & Cucurbitaceae & $\mathrm{E}$ & 10 & 9.3 & 0.16 & NS & SR & & $\mathrm{E}$ & \\
\hline 77 & Combretum albidum G.Don & Combretaceae & $\mathrm{D}$ & 10 & 8.2 & 0.53 & NS & $\mathrm{R}$ & NA & $\mathrm{S}$ & $\mathrm{Te}, \mathrm{Sp}$ \\
\hline 78 & Derris ovalifolia (Wight \& Arn.) Benth. & Papilionaceae & $\mathrm{E}$ & 4 & 13.1 & 0.13 & NS & $\mathrm{S}$ & NA & $\mathrm{E}$ & \\
\hline 79 & Dioscorea oppositifolia L. & Dioscoreaceae & $\mathrm{D}$ & 4 & 2 & 0.07 & NS & $\mathrm{S}$ & NA & $\mathrm{E}$ & \\
\hline 80 & Grewia rhamnifolia Heyne ex Roth & Tiliaceae & $\mathrm{B}$ & 10 & 11.6 & 0.14 & $S$ & $\mathrm{R}$ & NA & $\mathrm{D}$ & Mi, An \\
\hline 81 & $\begin{array}{l}\text { Gymnema sylvestre (Retz.) R.Br. ex } \\
\text { Schultes }\end{array}$ & Asclepiadaceae & $\mathrm{E}$ & 10 & 6.6 & 0.22 & $\mathrm{M}$ & $\mathrm{R}$ & $\mathrm{Y}$ & $\mathrm{E}$ & $\mathrm{Sp}$ \\
\hline 82 & Hugonia mystax $\mathrm{L}$ & Linaceae & $\mathrm{E}$ & 10 & 7.7 & 0.09 & NS & $\mathrm{R}$ & NA & $\mathrm{S}$ & \\
\hline 83 & Ichnocarpus frutescens (L.) R.Br. & Apocynaceae & $\mathrm{E}$ & 4 & 4.1 & 0.02 & $\mathrm{M}$ & $\mathrm{R}$ & $\mathrm{Y}$ & $\mathrm{E}$ & $\mathrm{Sp}$ \\
\hline 84 & Jasminum angustifolium (L.) Willd. & Oleaceae & $\mathrm{E}$ & 4 & 7.2 & 0.13 & NS & $\mathrm{R}$ & NA & $\mathrm{S}$ & $\mathrm{Te}$ \\
\hline 85 & Lantana camara $\mathrm{L}$. & Verbenaceae & $\mathrm{E}$ & 4 & 7 & 0.04 & NS & $\mathrm{R}$ & NA & $\mathrm{E}$ & \\
\hline 86 & Leptadenia reticulata (Retz.)Wight \& Arn & Asclepiadaceae & $\mathrm{B}$ & 4 & 5 & 0.07 & M & $\mathrm{R}$ & $\mathrm{W}$ & $\mathrm{E}$ & An \\
\hline 87 & Maerua oblongifolia (Forsk.) A.Rich. & Capparaceae & $\mathrm{E}$ & 4 & 4.3 & 0.06 & NS & SR & NA & $\mathrm{E}$ & \\
\hline 88 & Mukia maderaspatana (L.) M. Roem. & Cucurbitaceae & $\mathrm{B}$ & 4 & 3.4 & 0.04 & NS & SR & NA & $\mathrm{E}$ & \\
\hline 89 & Olax scandens Roxb. & Olacaceae & $\mathrm{E}$ & 4 & 16 & 0.14 & NS & $\mathrm{R}$ & NA & $\mathrm{E}$ & \\
\hline 90 & Pachygone ovata (Poir) Miers ex Hook. & Menispermaceae & $\mathrm{E}$ & 10 & 7.4 & 0.07 & NS & $\mathrm{S}$ & NA & $\mathrm{E}$ & $\mathrm{Te}, \mathrm{Sc}$ \\
\hline 91 & Plecospermum spinosum Trecul. & Moraceae & $\mathrm{E}$ & 4 & 14.5 & 0.83 & $\mathrm{M}$ & $\mathrm{R}$ & M & $\mathrm{S}$ & $\mathrm{Sp}$ \\
\hline 92 & $\begin{array}{l}\text { Premna corymbosa (Burm.f.) Rottl. \& } \\
\text { Willd. }\end{array}$ & Verbenaceae & $\mathrm{E}$ & 10 & 5.3 & 0.06 & NS & $\mathrm{S}$ & NA & $\mathrm{E}$ & \\
\hline 93 & Pyrenacantha volubilis Wight & Icacinaceae & $\mathrm{E}$ & 10 & 5.2 & 0.06 & NS & SR & NA & $\mathrm{E}$ & \\
\hline 94 & Reissantia indica (Willd.) Halle & Celastraceae & $\mathrm{E}$ & 10 & 9.6 & 0.05 & NS & SR & NA & $\mathrm{E}$ & \\
\hline 95 & Rivea hypocrateriformis (Desr.) Choisy. & Convolvulaceae & $\mathrm{E}$ & 4 & 12.2 & 0.1 & $\mathrm{M}$ & $\mathrm{S}$ & M & $\mathrm{E}$ & $\mathrm{Sp}$ \\
\hline 96 & Salacia chinensis L. & Hippocrtateaceae & $\mathrm{E}$ & 4 & 14.1 & 0.23 & NS & SR & NA & $\mathrm{E}$ & \\
\hline 97 & Strychnos lenticellata Hill & Loganiaceae & $\mathrm{E}$ & 10 & 5.9 & 0.05 & NS & SR & NA & $\mathrm{E}$ & \\
\hline 98 & $\begin{array}{l}\text { Tiliacora acuminata (Lam.) Hook. f. \& } \\
\text { Thoms. }\end{array}$ & Menispermaceae & $\mathrm{E}$ & 4 & 4.5 & 0.1 & NS & SR & NA & $\mathrm{E}$ & An, Mi \\
\hline 99 & $\begin{array}{l}\text { Tinospora cordifolia (Willd.) Hook. f. } \\
\text { \&Thoms. }\end{array}$ & Menispermaceae & $\mathrm{D}$ & 6 & 4.6 & 0.21 & NS & $\mathrm{R}$ & NA & E & \\
\hline
\end{tabular}




\begin{tabular}{|c|c|c|c|c|c|c|c|c|c|c|c|}
\hline \multirow{2}{*}{$\begin{array}{l}\text { Sl. } \\
\text { no. }\end{array}$} & \multirow{2}{*}{ Plant species } & \multirow{2}{*}{ Family } & \multirow{2}{*}{$\begin{array}{l}\text { Plant } \\
\text { type }\end{array}$} & \multirow{2}{*}{$\begin{array}{l}\text { Sampl } \\
\text { e size }\end{array}$} & \multirow{2}{*}{$\begin{array}{l}\text { Mean } \\
\text { girth } \\
(\mathrm{cm})\end{array}$} & \multirow{2}{*}{$\begin{array}{l}\text { Mean } \\
\text { bark } \\
\text { thickness } \\
(\mathrm{cm})\end{array}$} & \multirow{2}{*}{$\begin{array}{l}\text { Sap } \\
\text { quantity }\end{array}$} & \multirow{2}{*}{$\begin{array}{l}\text { Texture } \\
\text { R/SR/S }\end{array}$} & \multirow{2}{*}{$\begin{array}{l}\text { Sap colour } \\
\text { M/W/Y/N/R }\end{array}$} & \multirow{2}{*}{$\begin{array}{l}\text { Fissure } \\
\text { D/Di/S/E }\end{array}$} & \multirow[t]{2}{*}{ Fauna } \\
\hline & & & & & & & & & & & \\
\hline 100 & Toddalia asiatica (L.) Lam. & Rutaceae & $\mathrm{E}$ & 4 & 6 & 0.1 & NS & $\mathrm{S}$ & NA & $E$ & \multirow{6}{*}{ An } \\
\hline 101 & Toxocarpus kleinii Wight \& Arn. & Asclepiadaceae & $\mathrm{E}$ & 4 & 3.1 & 0.04 & S & SR & $\mathrm{W}$ & $\mathrm{E}$ & \\
\hline 102 & Tylophora indica (Burm. f.) Merr. & Asclepiadaceae & $\mathrm{D}$ & 4 & 3.7 & 0.1 & S & $\mathrm{S}$ & $\mathrm{W}$ & $\mathrm{E}$ & \\
\hline 103 & Ventilago madraspatana Gaertn. & Rhamnaceae & $\mathrm{E}$ & 4 & 37.1 & 0.48 & NS & $\mathrm{R}$ & NA & $\mathrm{S}$ & \\
\hline 104 & Wattakaka volubilis T. Cooke & Asclepiadaceae & $\mathrm{E}$ & 4 & 15.4 & 0.26 & S & SR & $\mathrm{W}$ & $\mathrm{E}$ & \\
\hline 105 & Ziziphus oenoplia (L.)Mill. & Rhamnaceae & $\mathrm{B}$ & 9 & 9.4 & 0.18 & NS & SR & NA & $\mathrm{E}$ & \\
\hline
\end{tabular}

\section{How to cite this article:}

Anil, K., Parthasarathy, N., 2016. Bark traits of woody species and bark resource use by faunal community in tropical dry evergreen forest of India. Int. J. Curr. Res. Biosci. Plant Biol. 3(2), 77-90. doi: http://dx.doi.org/10.20546/ijcrbp.2016.302.010 